\title{
Ramblings of an Old Academic: Unconfident Advice for End-Times Academics
}

\author{
James Paul Gee
}

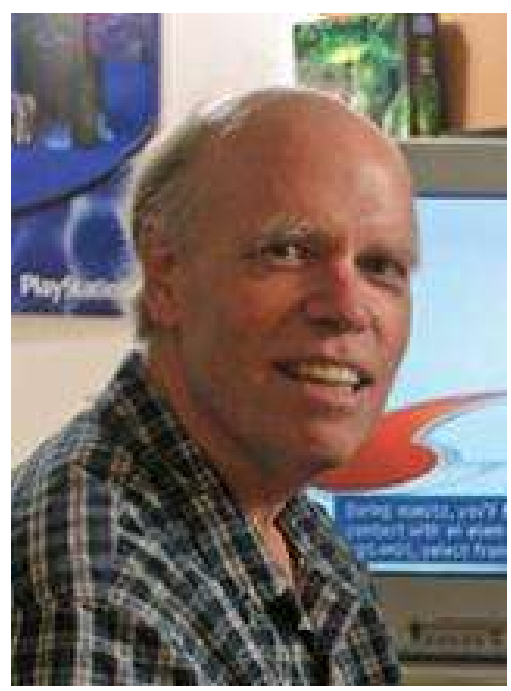

The last person anyone should take advice from about how be an academic today is me. First, I am a Baby-Boomer. We Baby-Boomers let colleges and the rest of the world go to hell in a handbasket on our watch.

Second, I have had an odd academic career. I have been a professor at six universities and tenured at seven (at one university where I ran for and got tenure, I never actually started the job). You do not accomplish such mobility by getting along with administrators.

Third, I have moved between two very different fields, theoretical linguistics and education. The first seemed to be rigorous, but to give answers to questions that weren't going to change the world. The latter seemed be messy, but to ask questions the answers to which, though never actually forthcoming, could change the world.

Fourth, I have worked and published in a many different areas: syntactic theory, philosophy of language, poetics, discourse analysis, psycholinguistics, sociolinguistics, discourse analysis, language development, ASL linguistics, deaf education, literacy, language teaching and learning, ESL, science education, new capitalism, learning theory, situated cognition, assessment, video games, multimodality, and on the root causes of human stupidity (or what Chomsky called "Orwell's Problem"). I wrote about these many different things because I always found it much easier to write about areas I did not yet know much about and much harder to say anything interesting or helpful when I knew lots about an area. So I just moved on.

Most significantly, the reason why no one should ask me for advice is that the world has changed so greatly in my lifetime. And it has changed in just the ways I was raised to believe it would never change. The realities to which I responded in my career are not the realities others today will have to respond to in their careers. Worse yet, it is entirely possible that the world never was the way I thought it was. 
Before I say how bad things are for young people today, let me say how good I, and others of my generation, had it. I was the first generation on either side of my family to go to college. I went to the University of California at Santa Barbara in the late, great 1960s, free of charge. I studied philosophy hard each day, all day, save in the later afternoons when I surfed in the Pacific Ocean on a beach filled with college students wearing next to nothing and sometimes nothing, for example, when protesting the Viet Nam War at "Nude Ins".

Because I had a good grade point average, the state of California paid all my tuition for my $\mathrm{MA}$ and $\mathrm{PhD}$ in linguistics at Stanford, the university up the road in Palo Alto from my home in pre-Silicon Valley San Jose, while Stanford paid me a stipend on which I lived comfortably without having to work or teach. I came out of all my degrees with no debt and no need for wealthy parents, which I did not have in any case.

When I was earning my PhD in linguistics at Stanford, my advisor Joan Bresnan left to take a job at MIT where she had been trained. Tom Wasow, her replacement in syntactic theory, who was to be my new advisor was not coming until the following year. I went to the chairman of the department and complained that I would be without an advisor in the interim. The chairman told me to go talk to Joan and pick anyone in the world and she would hire them to teach me for the next semester while I waited for Tom. I chose a great linguist from the University of Paris, Richie Kayne. The chairman called him in front of me and invited him to Palo Alto. He came and taught two classes.

One class was in a big lecture hall and I was the only student. Richie lectured from the stage and stopped every once in a while to look down into the dark audience area and ask if there were any questions. The other class was a seminar that had me as the only student and three faculty members auditing. Richie said in the opening class that each student taking the class for credit had to give a presentation in class about their work and since I was the only student my turn was the next class. I delivered a paper that had already received much praise and Richie, one of the greatest critics syntactic theory ever produced, destroyed it utterly. Utterly.

When, late in my graduate career, I had a "life crisis," wondering "What's it All Worth," and could no longer tolerate reading journals and writing articles nor my thesis, Stanford continued my fellowship and gave me a job teaching in the English Department until I got over it. I did.

For my first job after I got my degree I replaced my new advisor in his old job, all this having been nicely set up without a big hassle for me. At my new job, I was assigned an office the size of a closet, but befriended the elderly and founding secretary of the department and soon ended up in an office the size of a master bedroom suite in an old farm house.

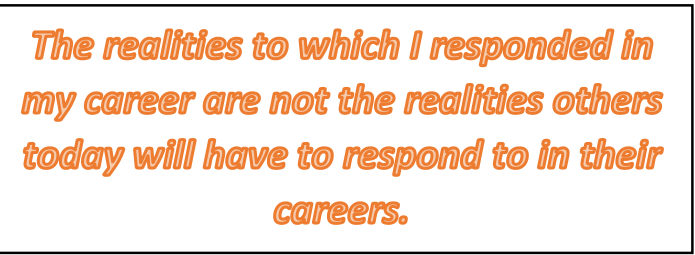

Every time I was nasty to and alienated administrators and had to leave my job, I was ushered into another job with a big raise, ending up with no roots, but a good salary. Now, an old man, I have yet again another "What's It All Worth" crisis in a world that is not as responsive to my needs as it once was.

By the way, in my generation, when you were nasty to administrators, you only got ushered into a new job with a big pay raise if and only if you kept your marketability by working more for SELF, INC. than you did for universities, who you very well knew did not have your interest at 
heart. Just as I emerged with my $\mathrm{PhD}$ in 1975, it became a buyers' market and, therefore, the powers that be did not think they had to treat faculty well and certainly never did so if you made it hard for yourself to up and leave.

As an aside I should mention that, in my old age, administrators and I have come to something of a mutual accommodation. I recently told my Provost that I would never again attend any committee meeting of any sort-as an old man I have too little time left in life to waste it that way-and she said, simply, "Who would want you on one?" It's nice finally to be understood.

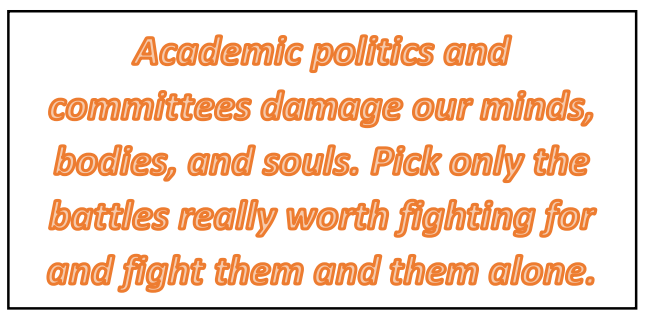

Well that's all gone. It's in my past and probably not in your future. If you are a graduate student, they probably are not going to call Paris for you. They are not going to reward your emotional crises. They are not going to fund everything generously. They are not going to pre-set-up your first job. They are not going to, as a job benefit, pay your child's full tuition at any college, public or private, in the United States, as one of my employers did; unfortunately, the child took this as an opportunity to sample a different private college each year, much like a buffet. You probably will not get to say nasty things to administrators and move on to a better paying job. Indeed, you may not even have tenure. And, remember, for us Baby Boomers it was tenure that saved us from being pink-slipped by the age of 45 so the company could hire a cheaper and more up-to-date employee, as happens now to people in jobs with no nets.

So why have things gotten worse just in time for you to come along and have an academic career? It's complicated, but I can make it simple. In the 1950s and 1960s the U.S dominated world markets and created the largest middle class in history, thanks in part to unions. In the 1970s the economy became global, jobs were out sourced to cheaper counties, unions weakened, and the destruction of the American middle class began. Eventually, as trading stocks based on short-term bets on their rise and fall each quarter became the major source of wealth, only the short-term stock price of a company came to matter, not what the company actually made and certainly not the employees who made it. Finally, financial elites came to see betting on more esoteric things than stocks-such things as derivatives, credit default swaps, and other high-risk financial fictions-as the way to garner great riches and thereby created our current casino capitalism and, with it, the highest levels of inequality in our history. Today, the United States, which once prided itself on high levels of upward social mobility has lower upward social mobility than many of the countries of old Europe, the ones we left in our revolution because of their class-bound cultures. Downward mobility is now the norm and that might mean YOU.

There was a time-between the end of WWII and the mid late 1970s - when the country at least seemed to operate by the idea that different institutional spheres had different goals and gave rise to different products. Businesses existed to make profit. Colleges existed to make knowledge. Hospitals existed to make people healthy. News media existed to inform the public. Churches existed to make people more moral. Profit was not supposed to be the bottom line for all institutions. Some institutions were meant to have enough insulation from the market to engage in "higher" goals. That's why public colleges and universities used to be generously supported by states and hospitals used to be viewed as charities. That's why we used to like public schools but now want our schools privatized and on a market. 
Today, all institutions are up against the market and expected to make money, even many so-called non-profits. Today colleges subordinate knowledge to grant getting. Hospitals subordinate health outcomes to money. News media subordinate information and truth to entertainment, propaganda, and profit gained by not offending corporations. Even churches subordinate religion to intemperate gain in mega-churches using mega-media. And, as I said above, businesses no longer make things, they really make stock prices and other more risky financial products that can be bet on in the short run, damn whatever happens to real things and to people.

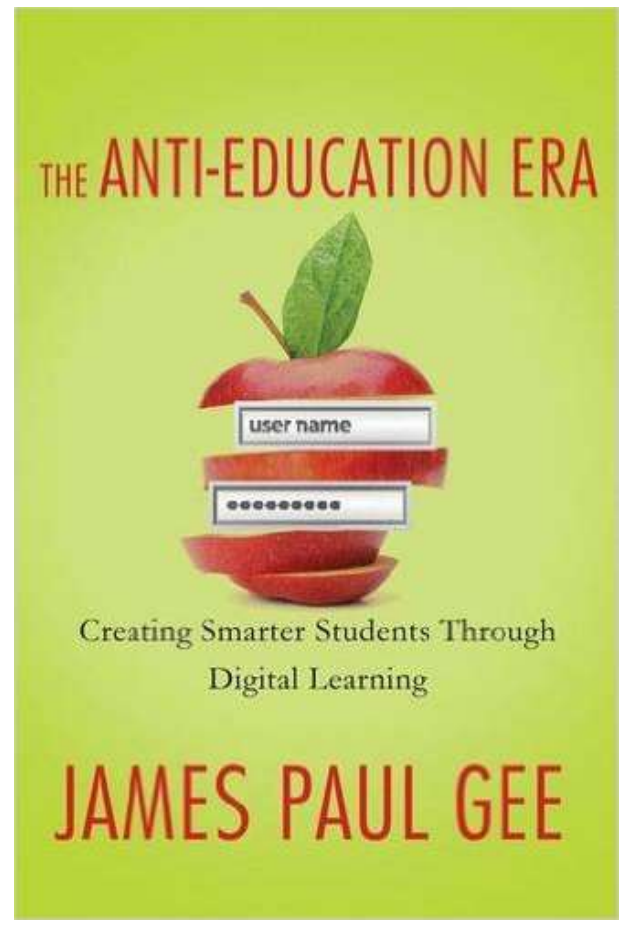

None of this is to say that there wasn't plenty of greed in the past, rather it is to say that we have now made greed a moral virtue and openly take pride in the fact that even in colleges and universities it is all about raising money. If a discipline can't get grants, then it is useless to the modern university. Ideas are judged in terms of potential financial gain. Our college and universities have rampant grade inflation because of the inherent conflict of interest between offering rigorous assessments and gaining and retaining ever more students' at ever higher tuition rates.

Now all these changes were part of a larger context of greed and a massive redistribution of wealth upwards. Human greed and stupidity has now led us to the brink of destruction. In the rush for profit and high lifestyles and ever greater riches we have created a world where interacting complex systems are going out of control. Global warming, environmental degradation, global casino capitalism, global poverty, global wars and conflicts, global religious fanaticism (not least in the U.S.), and global corporate imperialism are interacting to bring us a future fraught with peril, unpredictable change, diverse disasters, waves of immigration, wars over water, global pandemics, and the eradication of a great many species, possibly including one of the newest species on the planet Earth, us.

As another aside, it is stunning to realize that some $60 \%$ or more of Americans do not believe in evolution and nearly $30 \%$ believe the universe is less than 6000 years old and that dinosaurs and humans were on the earth at the same time. If you are among these people, do not bother going to college. Next to nothing you hear in a classroom in college will have more evidence behind it than evolution and the fact the universe is billions of years old, so why would you believe anything you hear from a college teacher?

So you want to be an academic? Business as usual - the way I and my fellow Baby-Boomers did it-probably isn't going to work for you. At least not for all of you. Only half the faculty at research universities are tenured or tenure track, only a third at non-research universities are-and the tenure and tenure-track numbers are only this big because the Baby-Boomers do not have to retire and they are clinging on for dear life. E-learning - a winner take all sort of game in which a single college could in principle supply a nearly endless number of 
distance students - is more and more the profit center for colleges and universities and is eradicating many a face-to-face programs and will eventually eradicate some of these colleges and universities. Getting grants counts more in universities than publishing in journals and publishing in journals - though it is still crucial for merit increases-has less impact than ever in a world where a paper put up on the Internet will be read by thousands more people than a journal article. And, too, in our new Open Source journal world academics are expected to pay to have their articles made widely available by a journal, many of which are now, like many conferences, fakes (put "predatory open-access journals" and "predatory academic conferences" into Google- the search titles tell you all you need to know about the sorry state of academic publishing today). Welcome to a world in which we choose what work to distribute widely based on money and not quality and yet claim to be in the knowledge business.

So what are you going to do? Almost all the literature on the future today agrees that things are so complex and risky at this point that all we can predict is great and chaotic change. This means, of course, that making choices based on the pastespecially Baby Boomer pasts-are not likely to be good ones. Colleges and universities are already undergoing great change and there is more to come. A young academic has a number of choices to make, choices that need to be made under conditions of great uncertainty.

One choice is whether to be an academic at all. Today, many college faculty teach as much as high school teachers and they teach courses that are no more advanced - and sometimes less advancedthan high school courses. There is more and more focus on what sort of job a college degree can get students and less and less interest in what used to be called a "liberal education". Tenure is being attenuated, exploited faculty associates are on the rise, many undergraduates are alienated from college as it now exists, and the competition for good tenure-track jobs is fierce in many areas, especially for graduate students not coming from prestigious departments and institutions.

Even if one chooses to be an academic, the nature of academic work has already changed a good deal. Traditionally, respected academics were narrow experts, devoting their work to developing their narrow and highly focused disciplinary subspecialty. This often amounted to working together with others on building an impressive structure brick by brick. Major figures, e.g., Chomsky in my field, had usually created the blue print and "worker bee" academics built the bricks, though sometimes making their own relatively small changes to the blue print. This approach to academics gave rise to impressive achievements, especially in the so-called "hard sciences". But, today, it has become problematic.

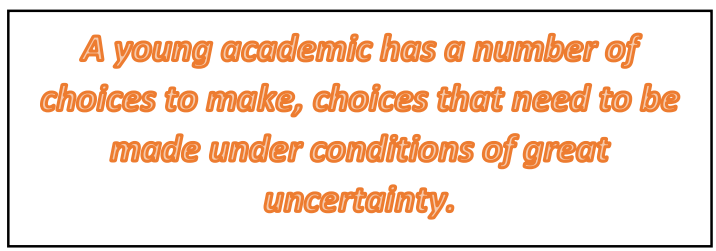

The major problems we face today are almost all to do with human affected complex systems and their interactions. We face complex challenges that transcend any one specialty domain. Traditional experts, like the economist Alan Greenspan-who ran the U.S. economy for decades and helped run it into the ground in 2008 - tend to over-value what they know and undervalue what they don't. They tend to see all problems to which their expertise is relevant solvable by that expertise largely unaided by other branches of knowledge.

Today, many academics work as parts of teams of people each of whom has his or her own special expertise and methods but works with the whole team on a big challenge or problem that requires 
collective intelligence and new integrated methods and theories. Each person on the team has to have deep expertise, but has to know how to integrate that expertise with other people's expertise and must come to share a common language and view of the big picture with the team. Such work can be hard in universities still organized around departments whose faculty really share little more than the room where they pick up their vanishing mail.

\section{Chances are your career will hove less and less ț do with your department

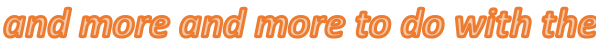 university @s whole and the wider" world outsidde your own mniversity.}

If one chooses to become this new academic (now a more and more common sort)—let's just call it being a "complexchallenge-based academic" - then one has to be careful to be trained and work in institutions that have the will and resources to engage in and support such research and researchers, especially untenured ones. A graduate student and young faculty member can no longer think just about the department they are in isolated from the larger picture of the institution as a whole. Chances are your career will have less and less to do with your department and more and more to do with the university as whole and the wider world outside your own university.

By the way, the spirit of working on complex challenges and not just problems narrowly defined in terms of a single discipline applies to college faculty who primarily teach rather than engage in research. A great part of the alienation of today's undergraduates is that we teach them water-downed versions of graduate disciplinary-based classes rather than dealing with challenges in a world of chaos, high risk, and constant change.
Another choice a new academic must make is whether to focus on traditional journal-based research or on what I will call "impact". Traditional research is published in good journals and judged by citations. Such research very often has had very little real impact on our problems, though, of course, some of it has a large impact even when at first the research seemed minor or strange. Impact means thinking of how our ideas and research can impact the world and our now serious problems more broadly while still retaining rigor and integrity.

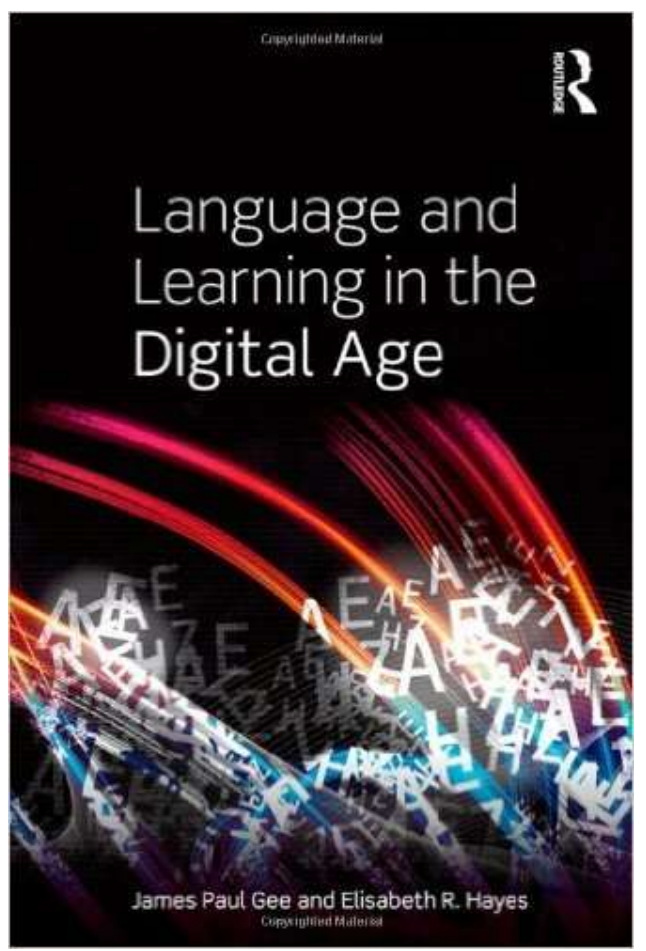

Today academics-like others-can use the Internet and many forms of communication beyond journals to influence a wide audience and engage ever larger numbers and types of people in dialogue. It is still common for some traditional academics to view this impact approach as "pandering" and to fail to reward it. Years ago when I worked solely in the area of syntactic theory I remember wondering what I would say to a grandchild far in the future, when I was old man, if the child ever asked me what I done with my life. I remember, in my mind, answering the child, "I worked on the grammar of naked 
infinitives and headless relative clauses". When I was younger, this answer sounded cool, as I aged it did not sound like it was a worth a life.

So do you want to be an academic? Don't do it if your heart is not really in it, certainly not now. Do you want to be a traditional academic or a complex-challengebased academic? Do you want to engage in traditional journal research or in impactbased forms of research and communication beyond whatever you do in traditional terms? What do you think is worth doing for the one human life you are going to get?

Let me add, based on having worked with lots of graduate students and young academics across the country, thanks to various grants, that these choices and issues play out quite differently for young academics with prestigious backgrounds, i.e., from the best degrees, mentors, departments, and institutions, and those with less prestigious backgrounds. Those with prestigious backgrounds often feel it is a big risk not to engage in business as usual in the traditional way. Even early on, they already appear to themselves to have too much to lose by taking risks. Those with less prestigious backgrounds often have less to lose and more to gain from taking bigger risks, since sticking to the traditional mainstream ways is not as likely to pay off for them given the competition. In our current complex setting, such people may actually have a certain advantage along with their disadvantages. But the truth is that, in our current world, we are all at risk of losing a great deal as our institutions, country, and whole world deteriorate under the blows of greed, change, and ignorance.

So I have no real advice that you should take without a massive grain of salt. But here it is any way:

1. Your job as an academic is to have ideas and to put them together with other people's ideas to make better ones with potential for real impact. This mission precedes thoughts of gain, publication, or fame.

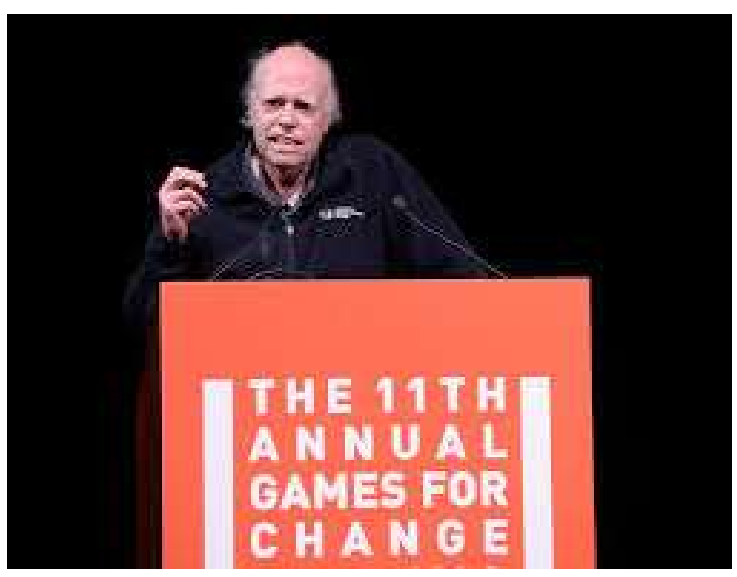

2. Keep one foot in your college or university activities and one foot outside in a related but different activities that create fruitful and sometimes unexpected synergies.

3. Do not worry over much about protecting your ideas. Let them out in the world early and often so they can get tested and promiscuously mate with other people's ideas. If someone steals one of your ideas and you were only going to have one good one anyway, then you would not have had a good career anyway-you have to have good ideas over the long haul.

4. Try to develop "taste", that is, good judgment about which ideas, yours or other people's, are tasty, deep, and have "legs" for impact into the future, even if at first they seem like weak fledglings.

Champion tasty ideas even if others are skeptical and even if they are not your ideas.

5. Pick your political battles carefully. Academic politics and committees damage our minds, bodies, and souls. Pick only the battles really worth fighting for and fight them and them alone. How do you know which these are? They are the ones that when you really think about it are worth taking real risks of damage to yourself and your career for. They are the ones where winning means making the world a better place. 
6. Good ideas often come from unexpected experiences, ones we are tempted not to follow up on because they might lead us away from our "field". Every book I have written was caused by following up a lead that at first seemed marginal and strange from the perspective of how I or others construed my "field". One example: I wrote a book on video games because my then six-year-old turned me onto them. While I was writing the book in 2001-2002 the whole idea seemed silly if I thought about it too much. I had Walter Mitty dreams of getting invited to the prestigious Game Developers Conference and creating a whole new field. None of this was likely to happen given that I was totally and utterly unknown in the world of games and given, too, at that time, no one much saw video games as relevant to literacy studies and vice-versa. But both things did happen.

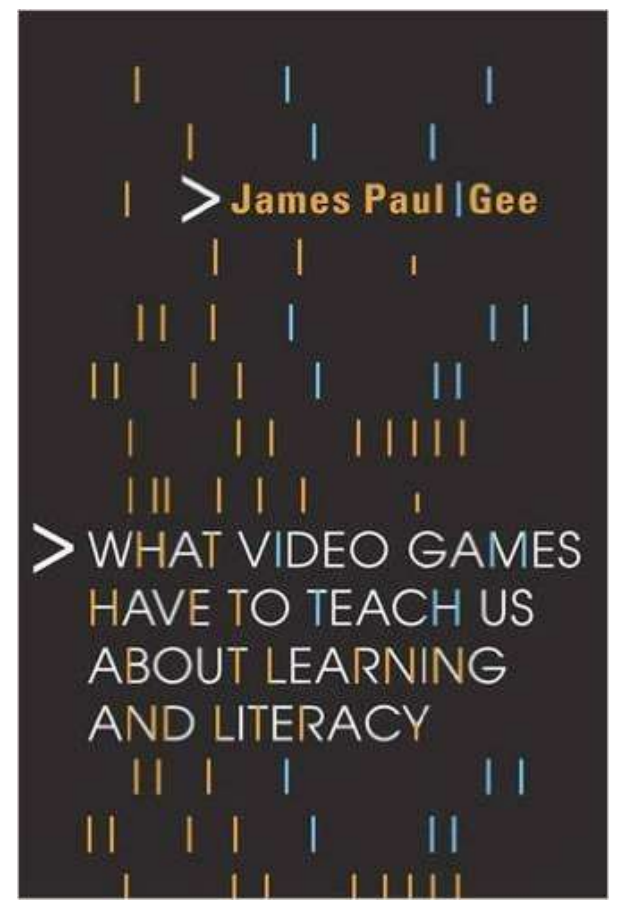

7. The "game" of life is nine innings, to use another sports metaphor. Never give up if you are behind. Play out all the innings and quit only when the fat lady sings. (Sorry again for, continuing the sports metaphor that might now be seen as insensitive to over-weight people.)
8. In my life I have never worried that I was paid less or was less well known than other people. I have only asked myself if I am happy with what I have and acted to get more if and only if I wasn't, not because other people had more. This has worked well, at least for me. I now know, having worked in education, that it is called a "mastery orientation" (competing with yourself and judging yourself by your own efforts and progress) and not an "achievement orientation" (competing to beat others and judging yourself by how you stand in relationship to others).

\section{In my life, I have never cared} whether I got the expected rewards others did at the same time as them or before them. I have always been a slow developer and arrived to each party, or stage of development a bit later than others. It seems only to have meant I got to savor some of the benefits later when others were already leaving the party.

10. The world is a mess. We need to at least put a finger in the collapsing dike until someone else can come up with a big idea to replace the whole thing. People will ask you how being an academic allowed you to do any real good in the world. Be sure that at the least your finger is in the dike and then tell them that's the good you did. That is all I was and am able to do. I have just tried to put my finger in the dike. As I get older I have the fantasy that what will replace the breaking dike and stem the flood is just a wall of people side by side with their fingers in the wall. Standing there, all together, getting wet, but holding the flood at bay, they will come to realize that it is not true that individuals cannot do anything in the face of big challenges. They can put a finger in the dike and yell for others to join them. They may well come to realize then that that wall of fingers in the dike is the big idea we were all waiting for. An idea no one had but everyone contributed to. An odd picture, but the one I end with. 
Note: This is an informal piece meant to be taken or left. I have not cluttered it with citations. Relevant citations to lots of the issues here can be found in my book The Anti-Education Era (2013). I had wanted to call the book On Human Stupidity, but the publisher wouldn't let me. As for the issues about today's colleges and universities, there are several relevant pieces on my site, jamespaulgee.com. You can also find innumerable books on the plight of colleges and universities today on Amazon.com. 


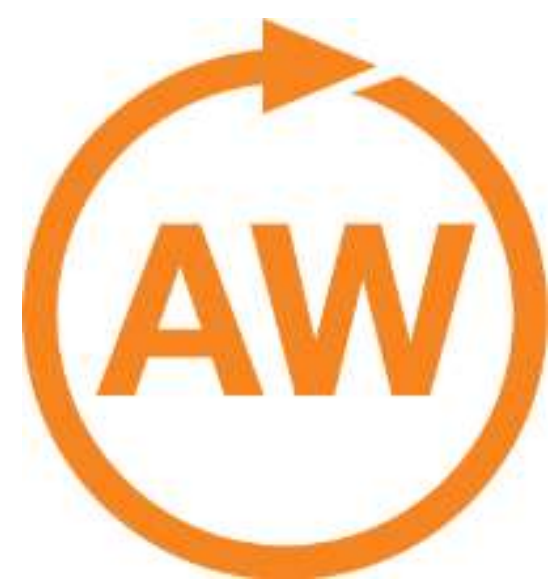

\section{About Acquired Wisdom}

This collection began with an invitation to one of the editors, Sigmund Tobias, from Norman Shapiro a former colleague at the City College of New York (CCNY). Shapiro invited retired CCNY faculty members to prepare manuscripts describing what they learned during their College careers that could be of value to new appointees and former colleagues. It seemed to us that a project describing the experiences of internationally known and distinguished researchers in Educational Psychology and Educational Research would be of benefit to many colleagues, especially younger ones entering those disciplines. We decided to include senior scholars in the fields of adult learning and training because, although often neglected by educational researchers, their work is quite relevant to our fields and graduate students could find productive and gainful positions in that area.

Junior faculty and grad students in Educational Psychology, Educational Research, and related disciplines, could learn much from the experiences of senior researchers. Doctoral students are exposed to courses or seminars about history of the discipline as well as the field's overarching purposes and its important contributors. .

A second audience for this project include the practitioners and researchers in disciplines represented by the chapter authors. This audience could learn from the experiences of eminent researchers-how their experiences shaped their work, and what they see as their major contributionsand readers might relate their own work to that of the scholars. Invitations to potential authors were accompanied by Tobias' chapter in this series for illustrative purposes.

Authors were advised that they were free to organize their chapters as they saw fit, provided that their manuscripts contained these elements: 1) their perceived major contributions to the discipline, 2) major lessons learned during their careers, 3) their opinions about the personal and 4) situational factors (institutions and other affiliations, colleagues, advisors, and advisees) that stimulated their significant work.

We hope that the contributions of distinguished researchers receive the wide readership they deserve and serves as a resource to the future practitioners and researchers in these fields. 


\title{
education review // reseñas educativas a multi-lingual journal of book reviews \\ editors: gustavo e. fischman / melissa cast-brede / gene v glass
}

Supported by the Mary Lou Fulton Teachers College, Arizona State University

\section{Acquired Wisdom}

\section{Edited by}

Sigmund Tobias

University at Albany

State University of New York
J. D. Fletcher

Institute for Defense Analyses

Alexandria VA

\section{David C. Berliner}

Arizona State University

Tempe AZ

\author{
Advisory Board Members \\ Gustavo Fischman, Arizona State University \\ Arthur C. Graesser III, Memphis State University \\ Teresa 1. McCarty, University of California Los Angeles \\ Kevin Welner, Colorado State University
}

\footnotetext{
ఠ
}

Education Review/Reseñas Educativas/Resenhas Educativas is supported by the edXchange initiative's Scholarly Communications Group at the Mary Lou Fulton Teachers College, Arizona State University. Copyright is retained by the first or sole author, who grants right of first publication to the Education Review. Readers are free to copy, display, and distribute this article, as long as the work is attributed to the author(s) and Education Review, it is distributed for non-commercial purposes only, and no alteration or transformation is made in the work. More details of this Creative Commons license are available at http://creativecommons.org/licenses/by-nc-sa/3.0/. All other uses must be approved by the author(s) or Education Review. Education Review is published by the Scholarly Communications Group of the Mary Lou Fulton Teachers College, Arizona State University.

Please contribute reviews at http://www.edrev.info/contribute.html.

Connect with Education Review on Facebook (https://www.facebook.com/pages/EducationReview/178358222192644) and on Twitter@EducReview 